
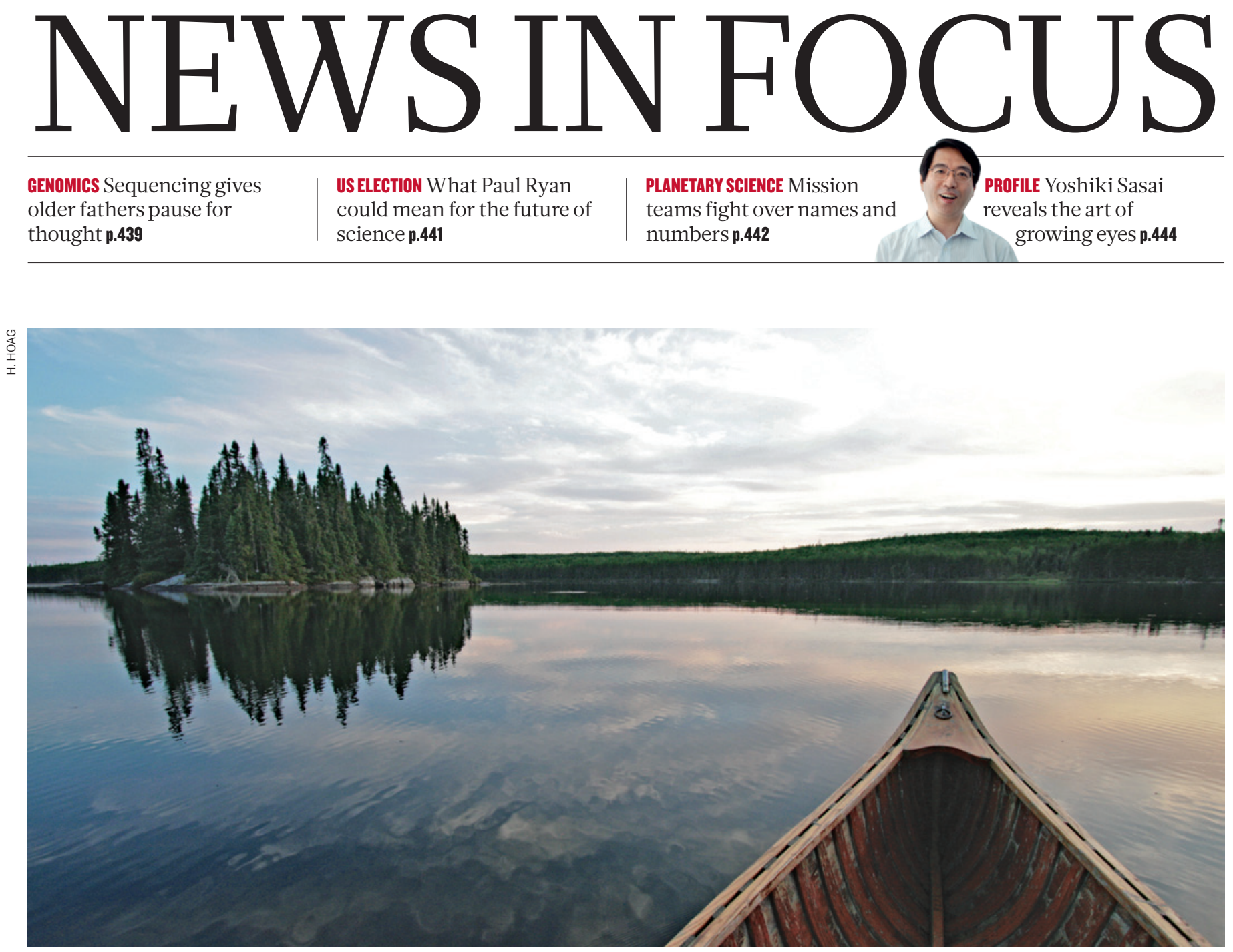

The isolated Experimental Lakes Area has been the site of landmark experiments on the sources and effects of pollution.

\title{
Test lakes face closure
}

\section{Slashed funding threatens Canada's unique freshwater study site.}

\section{BY HANNAH HOAG}

$\mathrm{L}$ ake 239 looks inviting. Pines and spruce fringe the shoreline and waves lap against outcrops of weathered granite. But on this hot August afternoon in northwestern Ontario (see 'Water works'), one feature stands out. At the far end of the 800-metre-long lake, a series of plastic-walled columns descend from a floating dock to the muddy bottom about 2 metres down. They are the sign that the lake's placid setting disguises an experiment in controlled environmental abuse.

Jennifer Vincent, a graduate student at Trent University in Peterborough, Ontario, kneels by one of the columns and empties a vial of silver nanoparticles into it. An iridescent purple cloud blooms in the water for a moment before the metal particles are mixed and disperse. These experiments are the first stage of a three-year, Can\$720,000 (US\$728,000) project to understand the biological effects of 'nanosilver' - an antibacterial agent commonly added to commercial products - and its possible effect on the environment. Previous work has shown that the chemical alters bacterial-community structure, affects algae and may change phosphorus cycling. Next year, the project intends to add nanosilver to an entire lake (Lake 222) and measure its effects across the ecosystem.

With 58 such lakes serving as sites for a broad range of studies, the Experimental Lakes Area (ELA) is unique in the world. "I don't

\section{DNATURE.COM}

For more on environmental cuts in Canada see: go.nature.com/717wpa take it lightly that you're basically poisoning a lake," says Chris Metcalfe, an environmental toxicologist from Trent University, and a leader on the project. But at the ELA, he adds, "you can graphically demonstrate what goes on in a whole lake ecosystem."

Yet the ELA project, with its laboratory buildings, residences and workshops, may soon disappear. Earlier this year, Canada announced that it would cease funding the ELA after March 2013, a development that dismayed scientists who have made use of the 44-year-old facility for investigations ranging from chemical contamination to the effects of climate change.

The decision was unexpected. On 17 May, ELA employees at the Freshwater Institute in Winnipeg, were called to an emergency meeting, where they were told that the 


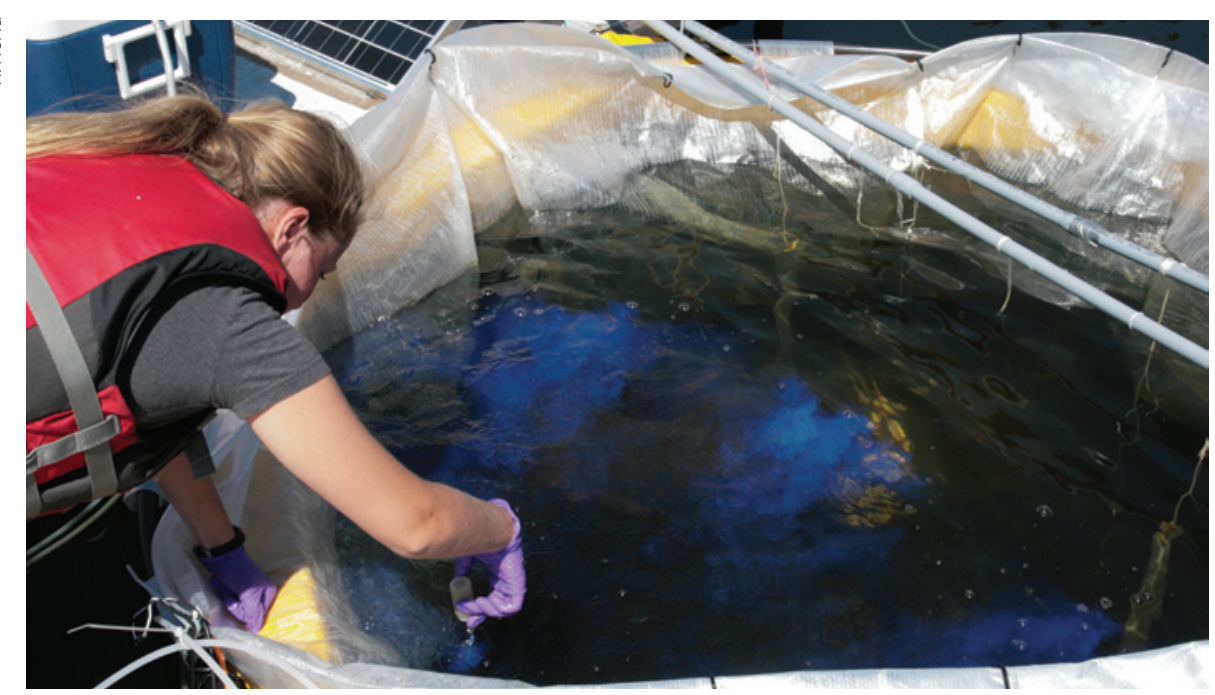

A three-year experiment to monitor the environmental effects of nanosilver particles faces cancellation.

government was no longer interested in experiments requiring whole-lake manipulation. The 17 ELA staff at the institute, including four scientists, who are employed by the Department of Fisheries and Oceans (DFO), were told that their positions will be axed as of April 2013.

\section{LAKES WITH A HISTORY}

Critics charge that the move reflects a broader hostility towards environmental science within the federal government. But Dave Gillis, director-general for ecosystem science at the DFO, maintains that the decision to cut the ELA's funding came down to priorities for spending at a time of fiscal restraint. In the federal government's budget released in March 2012 all departments faced reductions. The DFO's base budget of Can $\$ 1.36$ billion will drop by $5.8 \%$ (Can $\$ 79.3$ million) by 2015 . ELA supporters argue that the facility's small budget and high scientific value should prevent it from being a casualty. Its annual operating costs run to Can $\$ 600,000$, half of which is covered by Environment Canada, a separate department of the government, which has also cancelled its funding. Another Can $\$ 1.2$ million to 1.5 million from the DFO covers salaries.

The origin of the ELA dates back to the 1960s, when blooms of blue-green algae covered Lake Erie, and commercial and sport fish started to die off. Two enterprising scientists - Wally Johnson, the first director of the Freshwater Institute, and Ronald Hayes, chairman of the Fisheries Research Board of Canada (a precursor to the DFO) - told the Canadian and Ontario governments that they might be able to make sense of the problem if they could deliberately pollute a whole lake with fertilizer, thought to be the driver of the algal overgrowth that was starving Lake Erie of oxygen. In 1969, they got their wish, and began the experimental enrichment of Lake 227, one of several small, isolated lakes in an area that is underlain with impermeable bedrock that effectively contains the water and pollutants.

The study continued until the mid-1970s, and eventually included seven lakes. The most striking results emerged from Lake 226, where the researchers raised a plastic curtain across the narrow waist of the double-lobed lake and began adding carbon and nitrogen to one side and carbon, nitrogen and phosphorus to the other. The phosphorus side developed such a blanket of blue-green algae that it turned a stomach-churning chartreuse colour. "Those lake experiments are pretty well the thing that convinced politicians that we needed to control phosphate in detergents and sewage," says David Schindler, an ecologist at the University of Alberta, Edmonton, and one of the ELA's founding scientists. Canada and several US states have since banned phosphates from laundry and dishwasher detergents.

Since then, ELA scientists have dripped pollutants such as mercury, synthetic oestrogen and sulphuric acid into the lakes to explore their chemical impacts. They've built dams, constructed fish farms and drained wetlands to study the environmental outcomes of reservoir construction, aquaculture and climate change. The results have guided lawmakers in Canada and the United States to regulate sulphur dioxide and mercury emissions. "It's easy for regulatory agencies to dismiss research done in a lab, but it's less easy to dismiss work

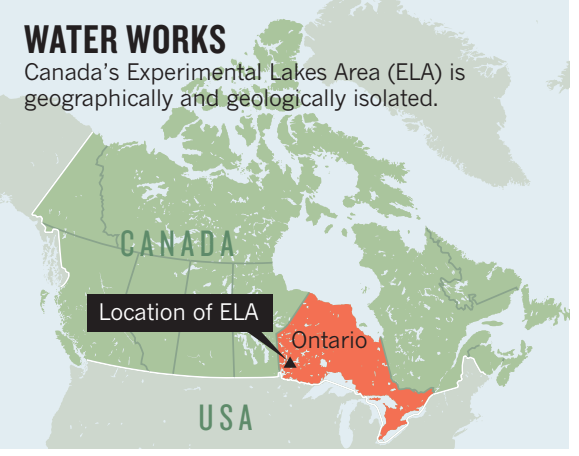

done in whole lakes," says Metcalfe. "People sit up and take notice."

These studies are now in jeopardy. This autumn, ELA scientists had planned to launch the second phase of an experiment designed to explore the ecological impact of transgenic fish, which might be used in future aquaculture. Domestic fish dosed with growth hormones would have served as proxies for the fast-growing transgenic varieties in experiments designed to study the effects of an accidental escape. Following this, the plan was to carry out a controlled release of transgenic fish by 2015. "The government should have a group of people to do the science that provides the evidence to direct environmental policy," says a DFO researcher, who asked to remain anonymous.

The timing of the announcement has ELA researchers confused. Several ELA projects received internal grants shortly before the defunding announcement. And the ELA's new Can $\$ 850,000$ fish biology laboratory - paid for by the federal government - has been open for just one field season.

Gillis, charged with finding a new benefactor, sets his sights on the universities. The DFO has said that it believes universities are better suited to conduct whole-lake ecosystem research. George Dixon, an aquatic toxicologist and vice-president for research at the University of Waterloo, Ontario, took part in discussions with the DFO in June. He says that the universities are cataloguing ELA research projects and sourcing budget details. "What will we use it for and how do we go about paying for it? We have to be very sure that we are going to get benefits in the future," he says. A meeting with the DFO will take place in September.

Many doubt that a new operator will be in place by next April, when the government funding expires - and some are dubious that one will be found at all. "Where's the money going to come from? Universities are barely getting by," says John Smol, a limnologist at Queen's University in Kingston, Ontario.

Another complication is that any new operator of the ELA could be liable for cleaning up the site. Legal documents show that any remediation, as well as the eventual rehabilitation of the lakes, watersheds, streams and land, is currently the responsibility of the federal government. Gillis says that the DFO has no estimate for that work. Diane Orihel, a graduate student in ecology at the University of Alberta, and the leader of a coalition to save the ELA, says that her research points towards a bill of tens of millions of dollars. "In terms of liability, universities are not interested in that," says Dixon.

Over coffee in the ELA lounge, Metcalfe says that he doesn't know if he should prepare Lake 222 for next summer's experiments. Yet he remains optimistic. "My hope is that there will be some sort of compromise between government agencies, universities and foundations," he says. 